Arctoa (2002) 11: 87-89

\title{
DICHELYMA CAPILLACEUM (DICKS.) MYR. (MUSCI) IN RUSSIA DICHELYMA CAPILLACEUM (DICKS.) MYR. (MUSCI) В РОССИИ
}

\author{
IRINA V. CZERNYADJEVA \\ ИРИНА В. ЧЕРНЯДЬЕВА
}

Abstract

\begin{abstract}
Dichelyma capillaceum (Dicks.) Myr. which has been known in Russia only in Leningrad Province, is found also in the West Siberian Plain. Its diagnostic characters, description, ecology and the differentiation from $D$. falcatum are provided.

Резюме

Dichelyma capillaceum (Dicks.) Myr., которая была известна в России только из Ленинградской области, найдена на Западно-Сибирской равнине. Приводятся описание, рисунки, экологическая характеристика вида, даются его отличия от D. falcatum.
\end{abstract}

Dichelyma capillaceum is widespread in boreal zone on eastern coast of the U.S.A. and Canada. In Europe it is rather common in southern Sweden and central Finland and sporadically occurs in Denmark, France, Germany, Poland, Italy, Romania (Red Data Book..., 1995). Toivonen (1972) and Hedenaes $\&$ al. (1996) considered in details the range of D. capillaceum and mapped its distribution. They regarded Dichelyma capillaceum as a boreal amphiatlantic species. Ingerpuu \& Vellak (1998) recorded Dichelyma capillaceum for Estonia. In Russia D. capillaceum has been found in the single locality in Leningrad Province (North-West Russia), by H. Lindberg in 1914.

Recently Dichelyma capillaceum was found by the author in the collections from West-Siberian Plain (Vah River, middle Ob River) (Fig. 1). Plants from Siberia are very similar to European ones. This discovery of $D$. capillaceum at the equal distances from both Atlantic and Pacific Oceans makes doubtful the definition of this species as amphiatlantic one. It is quite possible that further investigation of the territory of Siberia still insufficiently explored for bryophytes will result in new localities of this species.

Description of Dichelyma capillaceum based on the study of specimens from Russia is provided below.
Dichelyma capillaceum (Dicks.) Myr., K. Sv. Vet.-Akad. Handl. 1832:274, $1833 . \quad$ Fig. 2

Plants medium-sized, yellowish brown to brownish green, not glossy when dry. Stems to 5-9 cm long, loosely foliate, irregularly and sparsely branched. Leaves obscurely 3-ranked, erect-spreading, slightly to strongly falcatesecund when moist, twisted when dry, 4.3-5.2 $\mathrm{mm}$ long, 0.33-0.52 mm wide, linear-lanceolate, gradually narrowed to very long, narrowly acuminate apex, not or slightly decurrent, keeled; margin plane, entire below, frequently bistratose in the upper part; nerve single, 40-60 $\mu \mathrm{m}$ wide, excurrent in a long, aristate denticulate or smooth point of about 38-49\% the length of the leaf; median laminal cells $60-110 \times 4-7 \mu \mathrm{m}$, linear, slightly flexuose, thin-walled, smooth, eporose, basal laminal cells shorter and wider, slightly incrassate and porose, in leaf corners not different from other basal cells. Russian specimens sterile.

Dichelyma capillaceum is a very distinct species. In Russia the only other species of the genus Dichelyma occurs - D. falcatum (Hedw.) Myr., which is rather widespread in northern and mountain areas of the country. Russian specimens of Dichelyma capillaceum are distinct from the Russian material of D. falcatum in very long excurrent nerve, longer and narrower leaves, habit and some other characters (Table 1). However, in Sweden intermediate specimens

1 - Ботанический Институт им. В. Л. Комарова РАН, Проф. Попова 2, Санкт-Петербург 197376 - Komarov' Botanical Institue of Russian Acad. Sci., Prof. Popova 2, St.-Petersburg 197276 Russia 
Table 1. Comparison of Russian plants of Dichelyma capillaceum and D. falcatum

\section{Dichelyma capillaceum}

leaves

leaf length, mm leaf width, $\mathrm{mm}$

leaf length/width ratio nerve

leaf position on stem

leaf density linear-lanceolate

narrowed to very long apex

4.3-5.2

$0.3-0.5$

10-13: 1

excurrent $38-49 \%$

only obscurely 3 -ranked

loose

stem often seen among leaves

\section{Dichelyma falcatum}

lanceolate

narrowed to short apex

3.2-4.2

$0.6-1.2$

4-6: 1

subpercurrent to excurrent 3-7\% rather clearly 3-ranked

rather dense

stem invisible among leaves between these two species were reported. Hylander (1999) discussed this problem in details.

List of the Russian localities of Dichelyma capillaceum:

European Russia, Leningrad Region, Karelicus Isthmus, Muolaa, Lake Muolajarvi, mouth of Saaretjoki, 20.VI.1914, H. Lindberg (C, GB, H, LD, LE, S-PA, UPS).

West Siberia, $61^{\circ} 04^{\prime} \mathrm{N}, 80^{\circ} 13^{\prime} \mathrm{E}$, the middle course of Ob River area, Vah River, 4.VII.2000,
(\# 57), I.V. Czernyadjeva \& E.Yu. Kuzmina (LE).

Habitat. In Leningrad Province Dichelyma capillaceum grows "... ad radices arborum in aqua” (H. Lindberg). In West Siberia it grows on fallen branches in birch-wood in flood-lands with Leskea polycarpa Hedw.

\section{ACKNOWLEDGEMENTS}

I am very grateful to Dr. A. Potemkin for the help with English translation and to Dr. M. Ignatov for the help with figures.

Fig. 1. Distribution of Dichelyma capillaceum (Dicks.) Myr. in Russia.

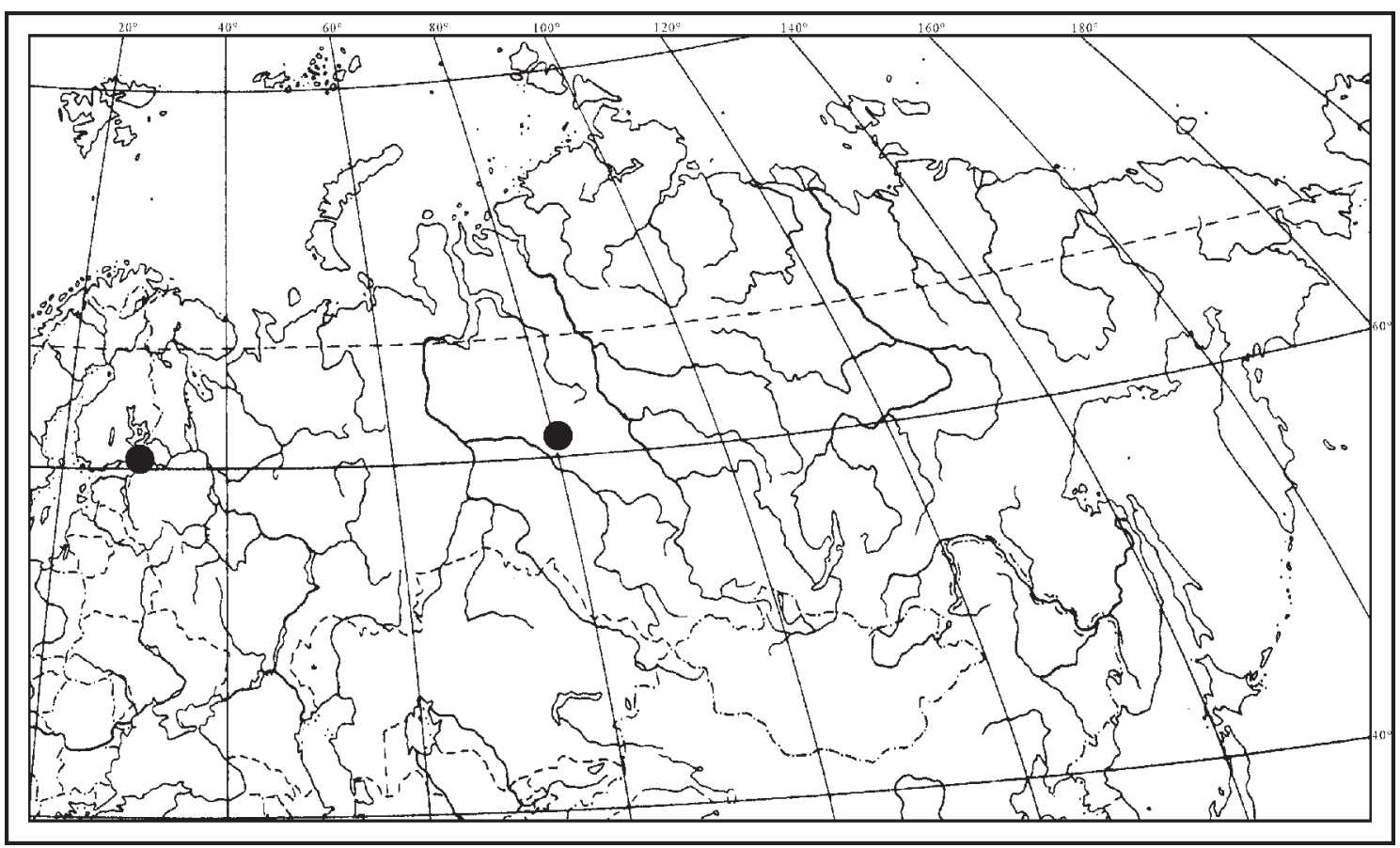




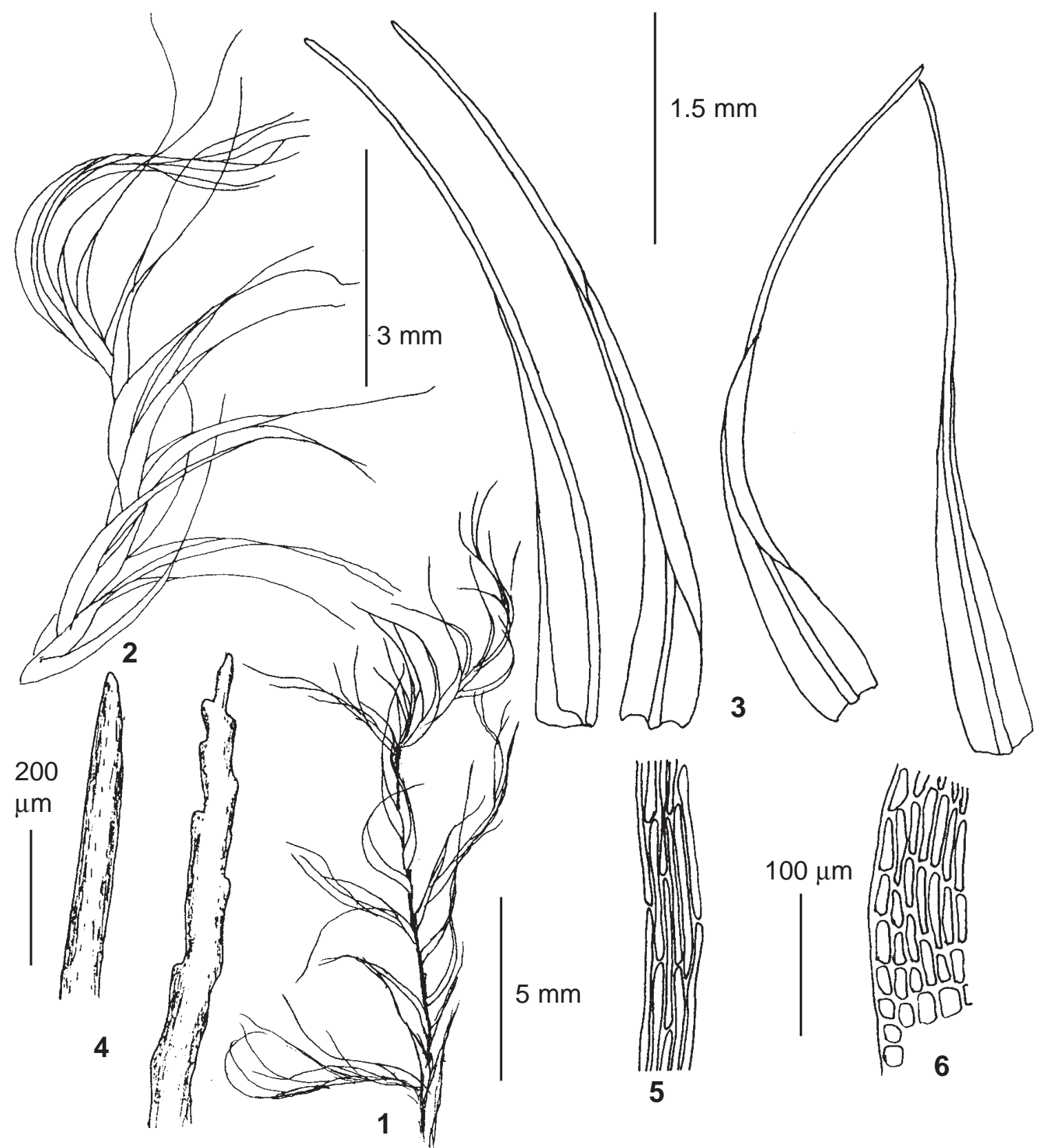

Fig. 2. Dichelyma capillaceum (Dicks.) Myr. (from Siberia, I.V. Czernyadjeva \& E.Yu. Kuzmina, \#57): 1, 2 - habit; 3 - leaves; 4 - upper parts of leaves; 5 - mid-leaf cells; 6 - basal leaf cells. Scale bars: $5 \mathrm{~mm}$ for $1,3 \mathrm{~mm}$ for $2,1.5 \mathrm{~mm}$ for $3,200 \mu \mathrm{m}$ for $4,100 \mu \mathrm{m}$ for 5,6 .

\section{LITERATURE CITED}

HEDENÄS, L, S. GODOW \& K. HYLANDER. 1996. Bryophyte Profiles. 1. Dichelyma capillaceum (Dicks.) Myr. (Bryopsida: Fontinalaceae). - J. Bryol. 19: 157179.

HYLANDER, K. 1999. Intermediates between the pleurocarpous mosses Dichelyma falcatum (Hedw.) Myr. and D. capillaceum (Dicks.) Myr., possible of hybrid origin. - Lindbergia 24: 59-64.
INGERPUU, N. \& K. VELLAK. 1998. Eesti sammalde määraja. - Tartu. $239 p p$.

RED DATA BOOK of European Bryophytes. 1995. Trondheim. $291 \mathrm{pp}$.

TOIVONEN, H. 1972. Distribution of Dichelyma capillaceum (With.) Myr. emend. Br. \& Schimp. (Bryophyta), especially in northwestern Europe. - Ann. Bot. Fennici. 9: 102-106. 